\title{
Receptors and neurotransmitters involved in the dual modulation of prolactin release by the serotoninergic system in pregnant and lactating rats
}

\author{
G. A. Jahn' ${ }^{1}$, V. Kalia' ${ }^{2}$, D. Hole ${ }^{2}$, C. A. Wilson ${ }^{2}$ and R. P. Deis ${ }^{1}$ \\ 'Laboratorio de Reproducción y Lactancia, CRICYT-CONICET, Casilla de Correos 855, 5500 Mendoza, Argentina; and 'Department of \\ Obstetrics and Gynaecology, St George's Hospital, London SW17 ORE, UK
}

\begin{abstract}
The receptors and neurotransmitter pathways that may participate in the inhibitory action of 5-hydroxytryptamine $(5 \mathrm{HT})$ on prolactin release during late pregnancy and lactation in rats were studied. Administration of the 5HT synthesis inhibitor, $p$ chlorophenylalanine, to late pregnant rats induced a significant increase in serum prolactin concentrations at 17:00 $\mathrm{h}$ on day 19 of pregnancy that was partially blocked by injections of the 5HT precursor, 5-hydroxytryptophan, or the 5HT agonists, 8-hydroxy2-(di-n-propylamino)-tetralin hydrobromide (S1a), 1-(2,5-dimethoxy-4-iodophenyl)-2aminopropane (S2) and $\mathrm{N}$-(3-chlorophenyl)imidodicarbonimide diamide $\mathrm{HCl}$ (S3), but not by RU 24969 (S1b) or 1-meta-(chlorophenyl)-piperazine-2- $\mathrm{HCl}$ (S1a-2c). The 5HT neurotoxins, fenfluramine and $p$-chloroamphetamine, which selectively destroy fine axon serotoninergic fibres but not coarse ones, prevented the increase in circulating prolactin observed at 18:00 h on pro-oestrus and on day 21 of pregnancy, but did not modify serum prolactin concentrations at $17: 00 \mathrm{~h}$ on day 19 of pregnancy. Administration of the adrenergic antagonists, metoprolol or prazosin, also prevented the stimulatory effects of $p$-chlorophenylalanine or ketanserin in pregnant rats on day $19(17: 00 \mathrm{~h})$ or on days 10-12 (16:30 h) in lactating rats separated from their litters. Administration of $p$-chlorophenylalanine to pregnant rats on day 19 reduced dopamine concentrations in the arcuate nucleus and in the anterior hypothalamus and noradrenaline concentrations in the anterior hypothalamus and the suprachiasmatic nucleus. These results indicate that the inhibitory actions of $5 \mathrm{HT}$ on prolactin release in pregnant and lactating rats are mediated by S1a, S2a and S3 receptors and by the coarse axon serotoninergic fibres. In addition, the inhibitory actions of 5HT may modulate the action of a stimulatory adrenergic pathway, as well as the concentrations of noradrenaline and dopamine in different hypothalamic areas, which, in turn, particularly arcuate nucleus dopamine, regulate prolactin release.
\end{abstract}

\section{Introduction}

5-Hydroxytryptamine (5HT or serotonin) has been implicated in the regulation of prolactin release in various physiological or experimental situations as a stimulatory agent (Wilson, 1979; Kordon et al., 1994). The general consensus is that S2 receptors mediate this action (Pan and Gala, 1988; Di Renzo et al., 1989; Jörgensen et al., 1993), although activation of S1 and S3 receptors also stimulates prolactin release in certain situations (Jörgensen et al., 1993; Kellar et al., 1992; Pan and Yang, 1996). Dual regulation of prolactin release by $5 \mathrm{HT}$ in pregnant and lactating rats (Jahn and Deis, 1987, 1988, 1994) has been demonstrated using the $5 \mathrm{HT}$ synthesis inhibitor, $p$-chlorophenylalanine (pCPA), the

Received 25 August 1998.
5HT receptor blockers, ketanserin (KET; S2a) and ICS 205930 (S3), and neurotoxic agents that selectively destroy fine serotoninergic axons (Mamounas et al., 1988; Appel et al., 1989; Molliver and Molliver, 1990), such as $p$ chloroamphetamine (pCA; Meek, 1978; Sanders-Busch and Steranka, 1978) and fenfluramine (FEN; Clineschmidt $e t$ al., 1978; Kleven and Seiden, 1989). Serotoninergic pathways participate in the stimulation of prolactin release in prooestrus, during the first 9 days of pregnancy and in suckling-lactating rats (Jahn and Deis, 1987, 1988, 1994). However, there seems also to be an inhibitory pathway, operative mainly at the end of pregnancy and in lactating rats that have been separated from their litters, that operates alongside the well known stimulatory pathway, at least in lactating rats (Jahn and Deis, 1994; Kordon et al., 1973/74). Comparison of the effects of the different agents used in 
lactating rats, especially those of $\mathrm{pCPA}$ and the neurotoxins, indicates that the stimulatory effects of $5 \mathrm{HT}$ are mediated by fine fibres and S2 receptors, while the inhibitory effects are mediated by the coarse fibres and S2 and S3 receptors (Jahn and Deis, 1994).

The hypothalamus is the main site of action of 5HT in the control of prolactin release (Wilson, 1979). Manipulation of serotoninergic pathways modifies dopaminergic and noradrenergic transmission (Burri et al., 1987; Nissbrandt et al., 1992; Blier et al., 1990; Done and Sharp, 1992; Blandina ef al., 1991) and these actions have been correlated with the effects on LH secretion (Burri et al., 1987). A relationship between serotoninergic and adrenergic pathways is of particular interest, since activation of noradrenergic pathways, through $\alpha_{1}$ and $\beta_{1}$ receptors, seems to mediate the release of prolactin induced by the decrease in progesterone at the end of pregnancy in rats (Jahn and Deis, 1991), a time when 5HT is inhibitory (Jahn and Deis, 1987, 1988).

The aim of the present study was to determine the receptors and neurotransmitter pathways that participate in the inhibitory action of 5HT on prolactin release during late pregnancy and lactation in rats. The effects of different 5HT agonists and adrenergic antagonists on the PCPA- or KETinduced prolactin release, the actions of PCPA and 5HT neurotoxins, and the effects of PCPA, administered at the end of pregnancy, on neurotransmitter concentrations in different hypothalamic areas were investigated.

\section{Materials and Methods}

\section{Animals}

Virgin female rats, 3-4 months old (200-220 g), bred in our laboratory and originally of the Wistar strain, were used. The rats were kept in a light (lights on 06:00-20:00 h)- and temperature $\left(22-24^{\circ} \mathrm{C}\right)$-controlled room; rat chow (Nutric, Cordoba) and tap water were available ad libitum. Vaginal smears were taken daily. Rats were caged individually with fertile males on the night of pro-oestrus, and the presence of spermatozoa was checked in the vaginal smear the next morning. This day was designated day 0 of pregnancy. The rats used during lactation were placed in individual cages 2-3 days before parturition, where they remained until used. The day of parturition was considered as day 0 of lactation. After delivery, the litters were adjusted to eight pups and the mothers were handled daily until the day of the experiment. Animal maintenance and handling were in accordance with the NIH guide for the Care and Use of Laboratory Animals (NIH publication numbers 86-23, revised 1985 and 1991) and the UK requirements for ethics of animal experimentation (Animals (Scientific Procedures) Act 1986).

Experiment 1: Effect of 5 HT agonists on serum prolactin concentrations in intact or $p C P A$-treated pregnant rats. Rats were injected s.c. with saline or pCPA (Sigma Chemical Co., St Louis, MO) injected at a dose of $200 \mathrm{mg} \mathrm{kg}^{-1}$ given in $1 \mathrm{ml}$ $\mathrm{kg}^{-1}$ saline at 12:00 h on day 18 of pregnancy (Jahn and Deis, 1987). Groups of pCPA- or saline-injected rats were injected with the following 5HT agonists i.p. at 16:30 h on day 19 of pregnancy: 5HTP (5-hydroxytryptophan, 5HT precursor; Sigma Chemical Co.) injected at a dose of $30 \mathrm{mg} \mathrm{kg}^{-1}$ given in $1 \mathrm{ml} \mathrm{kg}^{-1}$ saline (Jahn and Deis, 1987); 8-OH-DPAT (8hydroxy-2-(di- $n$-propylamino)-tetralin hydrobromide, S1a receptor agonist; RBI, Natick, MA) injected at a dose of $0.2 \mathrm{mg} \mathrm{kg}^{-1}$ given in $1 \mathrm{ml} \mathrm{kg}^{-1}$ saline (Kellar et al., 1992); RU 24969 (5-methoxy-3-(1,2,3,6-tetrahydro-4-pyridinyl)-1H indole succinate, S1a-S1b receptor agonist; generously provided by Roussel Uclaf, Romainville) injected at a dose of $5 \mathrm{mg} \mathrm{kg}^{-1}$ given in $1 \mathrm{ml} \mathrm{kg}^{-1}$ saline (Jörgensen et al., 1993); DOI (1-(2,5dimethoxy-4-iodophenyl)-2-aminopropane, S2a > S2c receptor agonist; RBI) injected at a dose of $0.2 \mathrm{mg} \mathrm{kg}^{-1}$ given in $1 \mathrm{ml} \mathrm{kg}^{-1}$ saline (Done and Sharp, 1992; Pan and Tai, 1992); mCPP (1meta-(chlorophenyl)-piperazine-2- $\mathrm{HCl}, \mathrm{S} 1 \mathrm{~b} / \mathrm{S} 2 \mathrm{c}>\mathrm{S} 2 \mathrm{a}$ receptor agonist; RBI) injected at a dose of $1 \mathrm{mg} \mathrm{kg}^{-1}$ given in $1 \mathrm{ml} \mathrm{kg}^{-1}$ saline (Quattrone et al., 1981; Pan and Tai, 1992); mCPBG ( $N$-(3-chlorophenyl)imidodicarbonimide diamide $\mathrm{HCl}, \mathrm{S} 3$ receptor agonist; $\mathrm{RBI}$ ) injected at a dose of $2 \mathrm{mg} \mathrm{kg}^{-1}$ given in $1 \mathrm{ml} \mathrm{kg}^{-1}$ saline (Higgins et al., 1993). Controls were injected with saline. The rats were killed by decapitation and trunk blood was collected at 17:00 h, since the effect of pCPA on serum prolactin concentration has been shown to reach a maximum at this time (Jahn and Deis, 1987). Serum was separated and stored at $-30^{\circ} \mathrm{C}$ for radioimmunoassay.

Experiment 2: Effect of $5 \mathrm{HT}$ neurotoxins on prolactin secretion in pro-oestrous and late pregnant rats. Four day cyclic rats on dioestrus 1 or rats on day 16 of pregnancy were injected s.c. at $12: 00 \mathrm{~h}$ with $10 \mathrm{mg} \mathrm{pCA} \mathrm{kg}^{-1}$ in $1 \mathrm{ml} \mathrm{kg}^{-1}$ saline, or with $15 \mathrm{mg}$ L-fenfluramine $\mathrm{kg}^{-1}$ (FEN; generous gift from $\mathrm{AH}$ Robins Co., Richmond, VA) in $1 \mathrm{ml} \mathrm{kg}^{-1}$ saline (Jahn and Deis, 1994). Another group of pregnant rats was injected with two doses of $200 \mathrm{mg}^{\mathrm{pCPA} \mathrm{kg}}^{-1}$ at $12: 00 \mathrm{~h}$ on days 18 and 20 of pregnancy. Saline injections were given to control rats at the same times and days. The virgin rats were killed at 18:00 $\mathrm{h}$ on the second pro-oestrus after treatment to allow time for the establishment of the neurotoxic action and the depletion of 5HT from the brain. Groups of pregnant rats subjected to the different treatments were killed at 17:00 h on day 19 or at 18:00 $\mathrm{h}$ on day 21 of pregnancy. At this time on day 21 there is a peak of prolactin concentration (Jahn and Deis, 1991). All rats were killed by decapitation and trunk blood was collected. Serum was separated and stored at $-30^{\circ} \mathrm{C}$ for radioimmunoassay.

Experiment 3: Adrenergic mediation of $p C P A$ or KET-induced prolactin release in pregnant and lactating rats. Pregnant rats on day 19 or lactating rats on days 10-12 of lactation that had been injected with $200 \mathrm{mg} \mathrm{pCPA} \mathrm{kg}^{-1}$ at 12:00 $\mathrm{h}$ the day before or with $10 \mathrm{mg} \mathrm{KET} \mathrm{kg}^{-1}$ p.o. at 12:00 h on the same day, were injected subsequently at 14:00 h with $3 \mathrm{mg}$ metoprolol (MET) $\mathrm{kg}^{-1}$, given i.p. in $1 \mathrm{ml} \mathrm{kg}^{-1}$ saline, $10 \mathrm{mg}$ prazosin (PRZ) $\mathrm{kg}^{-1}$, given i.p. in $1 \mathrm{ml} \mathrm{kg}^{-1}$ saline, or with saline only. The pregnant rats were killed at 17:00 h on day 19 of gestation. The lactating rats had been isolated from their litters at $08: 00 \mathrm{~h}$ and were killed at 16:30 h on the same day. Trunk blood was collected and serum was separated and stored at $-30^{\circ} \mathrm{C}$ for radioimmunoassay.

Experiment 4: Effect of pCPA on monoamine concentrations on 
different hypothalamic brain areas of late pregnant rats. Rats were injected s.c. with saline or $200 \mathrm{mg}$ pCPA kg-1 at 12:00 h on day 18 of pregnancy and killed at $17: 00 \mathrm{~h}$ on day 19 of pregnancy. Brains were rapidly removed and frozen on dry ice, and trunk blood was collected. Serum was separated and stored at $-30^{\circ} \mathrm{C}$ for radioimmunoassay. Brains were stored at $-80^{\circ} \mathrm{C}$.

\section{Tissue extraction and brain amine determinations}

The frozen brains were microdissected according to a modified method of Palkovits (1973). They were sectioned on a freezing microtome into $500 \mu \mathrm{m}$ slices, beginning at the union of the anterior commisure and ending at the mamillary peduncles. Cut in this manner, the hypothalamus is contained within 11 sections. Micropunches of the following areas were then taken: preoptic area (POA); suprachiasmatic nucleus (Sch); anterior hypothalamus $(\mathrm{AH})$; paraventricular nucleus (PVN); ventromedial hypothalamus (VMH); arcuate nucleus (Arc), using stainless steel punches of $0.7 \mathrm{~mm}$ internal diameter according to the method of Paxinos and Watson (1982). The samples were stored frozen at $-80^{\circ} \mathrm{C}$ in stoppered Beckman centrifuge tubes until assayed, which took place within 21 days.

The tissues were homogenized by sonication in $75 \mu \mathrm{l}$ 0.1 mol perchloric acid l-1 $^{-1}$ HPLC Grade; Merck, Lutterworth) and centrifuged for $15 \mathrm{~min}$ at $11000 \mathrm{~g}$ (Airfuge; Beckman ultracentrifuge). The monoamines in $50 \mu \mathrm{l}$ of the supernatants were measured without prior extraction by HPLC. Protein content in the remaining pellets was measured using the modified Coomassie blue method of Bradford (1976). The samples were injected via a Rheodyne 7125 injection valve into an Altex Ultrasphere ion pair $(5 \mu \mathrm{m})$ column $(15 \mathrm{~cm}$ long, $4.6 \mathrm{~mm}$ outer diameter), protected by a guard column (Uptight Pre-column Kit C-135-B; Jones Chromatography Ltd, Hengoed). The neurotransmitters were measured by an LC4 amperometric controller (BAS Technical Ltd, Luton), set in oxidative mode with a potential of $+0.7 \mathrm{~V}$ versus an $\mathrm{Ag}-\mathrm{AgCl}$ reference electrode (Model TL 5A; BAS Technical Ltd). The mobile phase consisted of filtered and degassed 0.1 mol citric acid ${ }^{-1} ; 25 \mathrm{mmol} \mathrm{NaOH}^{-1}, \mathrm{pH} 3.55 ; 1$ mmol EDTA $\mathrm{l}^{-1}, 6 \%$ acetonitrile; and $1 \mathrm{mmol}$ heptane sulphonate $\mathrm{l}^{-1}$ as the ion pair reagent, with a flow rate of $1 \mathrm{ml} \mathrm{min}^{-1}$ and 3,4-dihydroxybenzylamine (DHBA) as internal standard. Chromatograms were analysed by a Schimadzu CRSA Chromatopac integrator (Dyson Instruments, Hetton, Tyne and Wear) and the sensitivity was approximately $25 \mathrm{pg}$ for 5HT and 5-hydroxy indole acetic acid (5-HIAA), and $15 \mathrm{pg}$ for noradrenaline, dopamine and 3,4-dihydroxyphenyl acetic acid (DOPAC). Results are expressed as $\mathrm{ng} \mathrm{mg}^{-1}$ protein.

\section{Prolactin determination}

Prolactin was measured by double antibody radioimmunoassay using materials generously provided by the NIADDK (S. Raiti, NIADDK, Pituitary Hormone Distribution Program). The hormone was radio-iodinated using the
Chloramine $\mathrm{T}$ method and purified by passage through Sephadex G75. The results were expressed in terms of the rat prolactin RP-3 standard preparation. Assay sensitivity was $0.5 \mu \mathrm{g} \mathrm{l}^{-1}$ serum and the inter- and intra-assay coefficients of variation were $<10 \%$.

\section{Statistical analysis}

Statistical analysis was performed using one or two-way analysis of variance (ANOVA) followed by the least significant difference between means $(t)$ test, or by Student's $t$ test, when only two means were compared (Snedecor and Cochran, 1967). Differences between means were considered significant at $P<0.05$.

\section{Results}

Effect of 5 HT agonists on serum prolactin concentrations in intact or $\mathrm{DCPA-treated} \mathrm{pregnant} \mathrm{rats}$

The administration of different 5HT agonists, or of the precursor 5HTP, did not modify basal serum prolactin concentrations in rats at 17:00 h on day 19 of pregnancy (Fig. 1). However, restitution of 5HT concentration by 5HTP injection prevented, in part, the increase in serum prolactin provoked by $\mathrm{PCPA}$, demonstrating that the effect of PCPA is due to its 5HT lowering action, and not to secondary effects. Administration of 8-OH DPAT, DOI, and MCPBG also prevented, in part, the effect of PCPA, indicating the participation of S1a, S2a, and S3 receptors in the action of pCPA. However, S2c and S1b receptors did not seem to participate, since RU 24969 did not modify serum prolactin concentrations and $\mathrm{mCPP}$ produced a decrease that did not achieve statistical significance (Fig. 1).

\section{Effect of 5HT neurotoxins on serum prolactin concentrations in pro-oestrous and late pregnant rats}

Rats treated on day 1 with FEN or PCA at neurotoxic doses had significantly reduced preovulatory surges of prolactin at 18:00 $\mathrm{h}$ on the pro-oestrus 6 days after treatment (Fig. 2). In contrast to the effect of pCPA (Fig. 1), there was no effect of the neurotoxins on day 19 of pregnancy at 17:00 h. On day 21 at $18.00 \mathrm{~h}$, the neurotoxins also significantly reduced the prepartum surge of prolactin, while two doses of $200 \mathrm{mg}$ pCPA kg-1 given at 12:00 h on days 18 and 20, did not alter prolactin concentrations (Fig. 2).

\section{Effect of adrenergic antagonists on serum prolactin concentrations in intact $p C P A$-or ketanserin-treated pregnant or lactating rats}

Activation of the $\alpha_{1}$ and $\beta_{1}$ noradrenergic receptors mediates the increase in prolactin secretion induced by the decrease in progesterone at the end of pregnancy (Jahn and Deis, 1991). Thus, it was investigated whether the prolactin- 


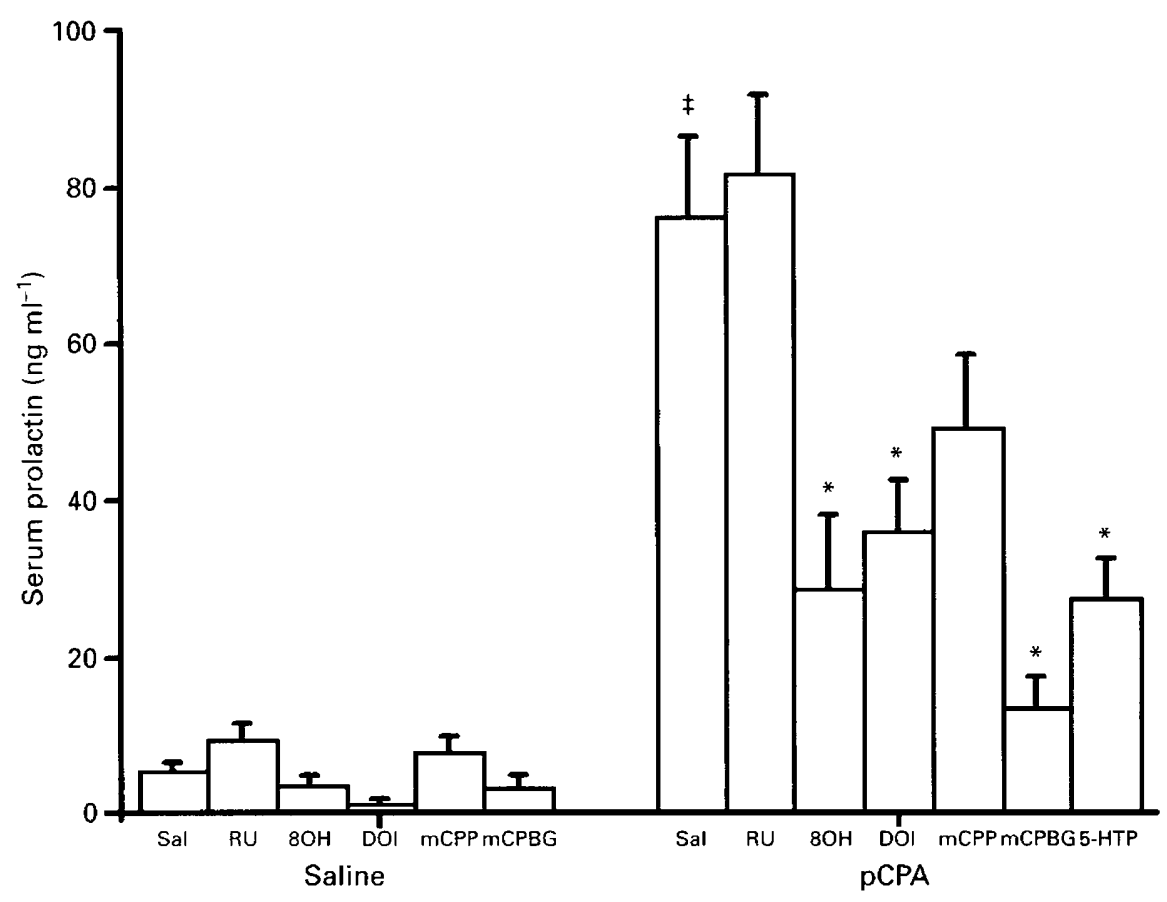

Fig. 1. The effect of different 5-hydroxytryptamine $(5 \mathrm{HT})$ agonists on basal and $p$ chlorophenylalanine (pCPA)-stimulated (200 $\mathrm{mg} \mathrm{pCPA} \mathrm{kg}^{-1}$, s.c. given at 12:00 h on day 18) serum prolactin concentrations in rats on day 19 of pregnancy. All agonists were injected s.c. at $16: 30 \mathrm{~h}$ and the rats bled by decapitation $30 \mathrm{~min}$ later. Sal: Saline; $8 \mathrm{OH}$ : 8 -hydroxy-2-(di- $n$ propylamino)-tetralin hydrobromide, Sla receptor agonist, injected at a dose of $0.2 \mathrm{mg} \mathrm{kg}^{-1}$; RU: RU 24969, S1a-Slb receptor agonist injected at a dose of $5 \mathrm{mg} \mathrm{kg}^{-1}$; DOI: $1-(2,5-$ dimethoxy-4-iodophenyl)-2-aminopropane, S2a $>$ S2c receptor agonist injected at a dose of $0.2 \mathrm{mg} \mathrm{kg}^{-1}$; mCPP: 1-meta-(chlorophenyl)-piperazine-2- $\mathrm{HCl}, \mathrm{S} 1 \mathrm{~b} / \mathrm{S} 2 \mathrm{C}>\mathrm{S} 2 \mathrm{a}$ receptor agonist injected at a dose of $1 \mathrm{mg} \mathrm{kg}^{-1}$; mCPBG: $N$-(3-chlorophenyl)imidodicarbonimide diamide $\mathrm{HCl}, \mathrm{S} 3$ receptor agonist injected at a dose of $2 \mathrm{mg} \mathrm{kg}^{-1}$; 5HTP: 5-hydroxytryptophan, 5HT precursor, injected at a dose of $30 \mathrm{mg} \mathrm{kg}^{-1}$ given in $1 \mathrm{ml} \mathrm{kg}^{-1}$ saline. $\neq P<0.05$ compared with control saline group. ${ }^{*} P<0.05$ compared with respective $\mathrm{pCPA}$-treated group (Snedecor and Cochran, 1967). Values represent the means \pm SEM of groups of eight rats.

stimulating effects of pCPA and ketanserin in late pregnant rats (Jahn and Deis, 1988) are also mediated by this pathway. Administration of the $\alpha_{1}$ adrenergic antagonist, prazosin, or of the $\beta_{1}$ adrenergic antagonist, metoprolol, significantly prevented the increases in prolactin provoked by PCPA or KET on day 19 of pregnancy, at 17:00 h (Fig. 3a). pCPA and KET also increase the basal serum prolactin concentrations in lactating rats isolated from their litter for $8 \mathrm{~h} 30 \mathrm{~min}$ (Jahn and Deis, 1994). The adrenergic antagonists blocked the effects of PCPA and KET in 'lactating isolated' rats (Fig. 3b).

\section{Effect of $p C P A$ on monoamine concentrations in selected brain areas of day 19 pregnant rats}

pCPA markedly reduced 5HT and 5-HIAA concentrations to $10-20 \%$ of control values on all the brain nuclei studied, while the effects on the other neurotransmitters varied depending on the brain area. PCPA treatment significantly decreased noradrenaline concentrations in the anterior hypothalamus (controls: $11.74 \pm 1.25$ versus PCPA: $7.5 \pm 0.39$ ng mg ${ }^{-1}$ protein; $P<0.05$ ) and in the suprachiasmatic nuclei (controls: $14.3 \pm 2.85$ versus pCPA: $7.13 \pm 0.88 \mathrm{ng} \mathrm{mg}^{-1}$ protein; $P<0.05)$, and dopamine concentrations in the anterior hypothalamus (controls: $2.18 \pm 0.19$ versus pCPA: $1.01 \pm 0.13 \mathrm{ng} \mathrm{mg}^{-1}$ protein; $P<0.05$ ) and the arcuate nuclei (controls: $3.27 \pm 0.45$ versus pCPA: $1.74 \pm 0.25 \mathrm{ng} \mathrm{mg}^{-1}$ protein; $P<0.05$ ) and DOPAC in the preoptic area (controls: $0.45 \pm 0.12$ versus PCPA: $0.14 \pm 0.05 \mathrm{ng} \mathrm{mg}^{-1}$ protein; $P<0.05)$. There were no effects of $\mathrm{pCPA}$ on noradrenaline, dopamine or DOPAC in the paraventricular nucleus or in the ventromedial hypothalamus.

\section{Discussion}

The overall picture of steroid action arising from our study of the regulation of prolactin release at the end of pregnancy over a number of years in the rat is that progesterone is inhibitory to prolactin release at the end of pregnancy. The decrease in progesterone after luteolysis triggers prolactin release, and the increase in oestrogen secretion observed 


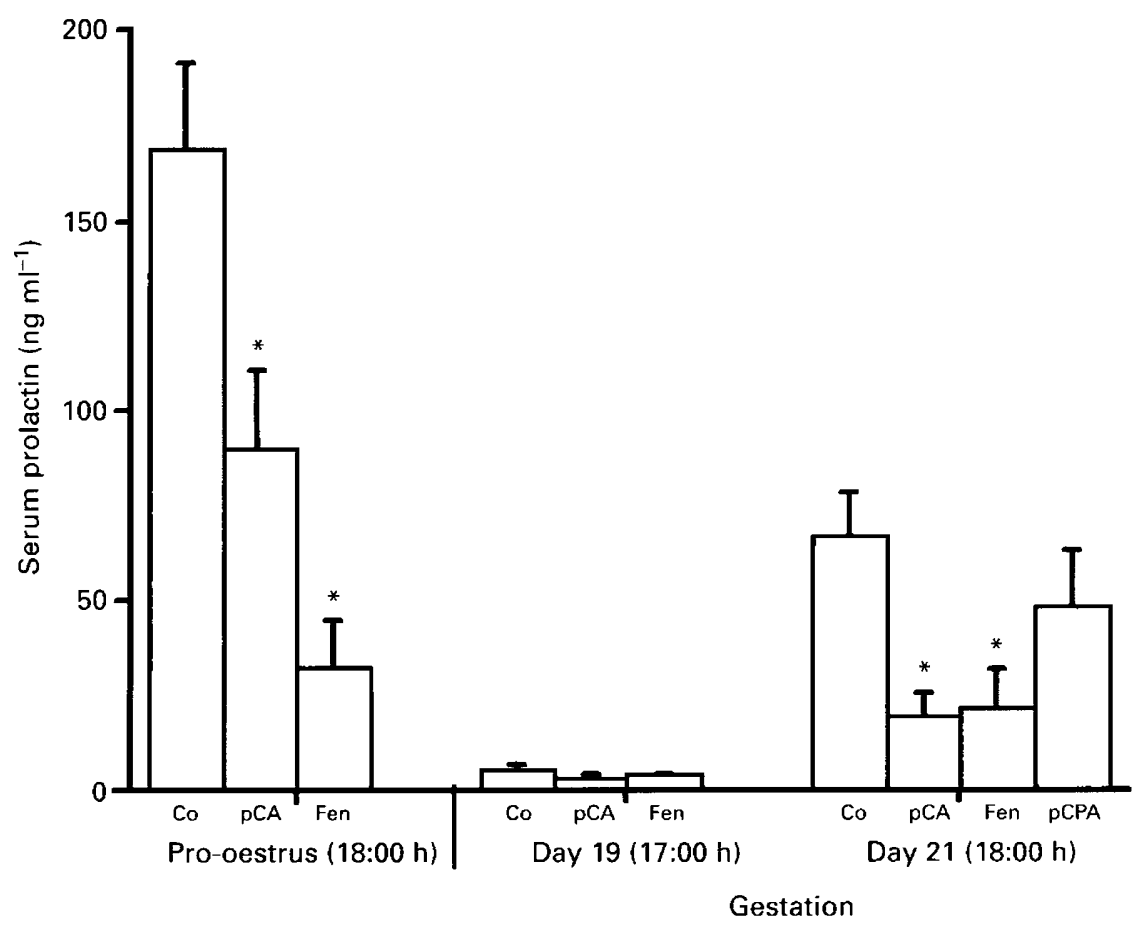

Fig. 2. Effects of $p$-chlorophenylalanine (pCPA) or the 5-hydroxytryptamine (5HT) neurotoxins, L-fenfluramine (FEN) or $p$-chloroamphetamine (PCA), on serum prolactin concentrations in rats at 18:00 h on pro-oestrus, at 17:00 $\mathrm{h}$ on day 19, or at 18:00 h on day 21 of pregnancy. Four-day cyclic rats on dioestrus 1 or rats on day 16 of pregnancy were injected s.c. at $12: 00 \mathrm{~h}$ with $10 \mathrm{mg} \mathrm{pCA} \mathrm{kg}{ }^{-1}$ or with $15 \mathrm{mg}$ Fen kg-1. Another group of pregnant rats were injected with two doses of $200 \mathrm{mg} \mathrm{PCPA} \mathrm{kg}^{-1}$ at 12:00 h on days 18 and 20 of pregnancy. Controls $(\mathrm{Co})$ were injected with saline. Virgin rats were killed on the second pro-oestrus after the neurotoxin injections. All rats were bled by decapitation. ${ }^{*} P<0.05$ compared with respective control group (Snedecor and Cochran, 1967). Values represent the means \pm SEM of groups of $8-10$ rats.

before delivery potentiates this effect, increasing further the concentrations of prolactin (Vermouth and Deis, 1974; Jahn and Deis, 1987). The serotoninergic, adrenergic and opioid systems have been studied using diverse pharmacological approaches (Jahn and Deis, 1987, 1988, 1991, 1994; Soaje and Deis, 1994, 1997) to attempt to elucidate the neurotransmitters and pathways involved in the regulatory action of progesterone. 5-Hydroxytryptamine and opioids, which in most circumstances stimulate prolactin release, were found to be inhibitory at the end of pregnancy, while adrenergic agents, which do not seem to have an important participation in physiological stimulation of prolactin release (by pro-oestrus, lactation or stress), were clearly stimulatory. However, the inhibitory action of 5HT does not seem to be related or to mediate the inhibitory action of progesterone, since the effect of $\mathrm{PCPA}$ is similar in intact and in ovariectomized pregnant rats and, conversely, no 5HT antagonists so far tested prevent the increase in prolactin induced by the progesterone decrease (Jahn and Deis, 1987, 1988). Thus, the neural pathways and neurotransmitters implicated in the regulation of prolactin secretion at late gestation in rats seem to be markedly different from those of other reproductive or physiological situations.
In the present study, the mechanisms and receptors implicated in the paradoxical inhibitory action of $5 \mathrm{HT}$ in late pregnancy and in lactating rats were investigated. Present and previous (Jahn and Deis, 1987, 1988, 1994) data show that the 5HT neurotoxins, FEN and pCA, mimicked the effects of inhibition of $5 \mathrm{HT}$ synthesis by pCPA in pro-oestrus and in suckled lactating rats, while they did not reproduce the stimulation of prolactin secretion induced by pCPA or KET at the end of pregnancy or in lactating rats isolated from the litter. Since the neurotoxins affect only the serotoninergic fine axon pathways, it may be concluded that, in pregnant rats, as in lactating rats (Jahn and Deis, 1994), the fine axon $5 \mathrm{HT}$ pathways mediate the stimulatory actions of $5 \mathrm{HT}$, while the coarse axon pathways mediate the inhibitory actions of the neurotransmitter. Furthermore, pCA and FEN also inhibited the prolactin surge observed on day 21 of pregnancy, when progesterone has decreased after luteolysis, while pCPA had no significant effect. In the case of pCPA, it is possible that the generalized inhibition of 5HT synthesis in both coarse and fine grained axon pathways may have led to an equilibrium between stimulatory and inhibitory actions.

The effects of the different 5HT agonists upon the pCPAinduced prolactin release, within the limitations of the 

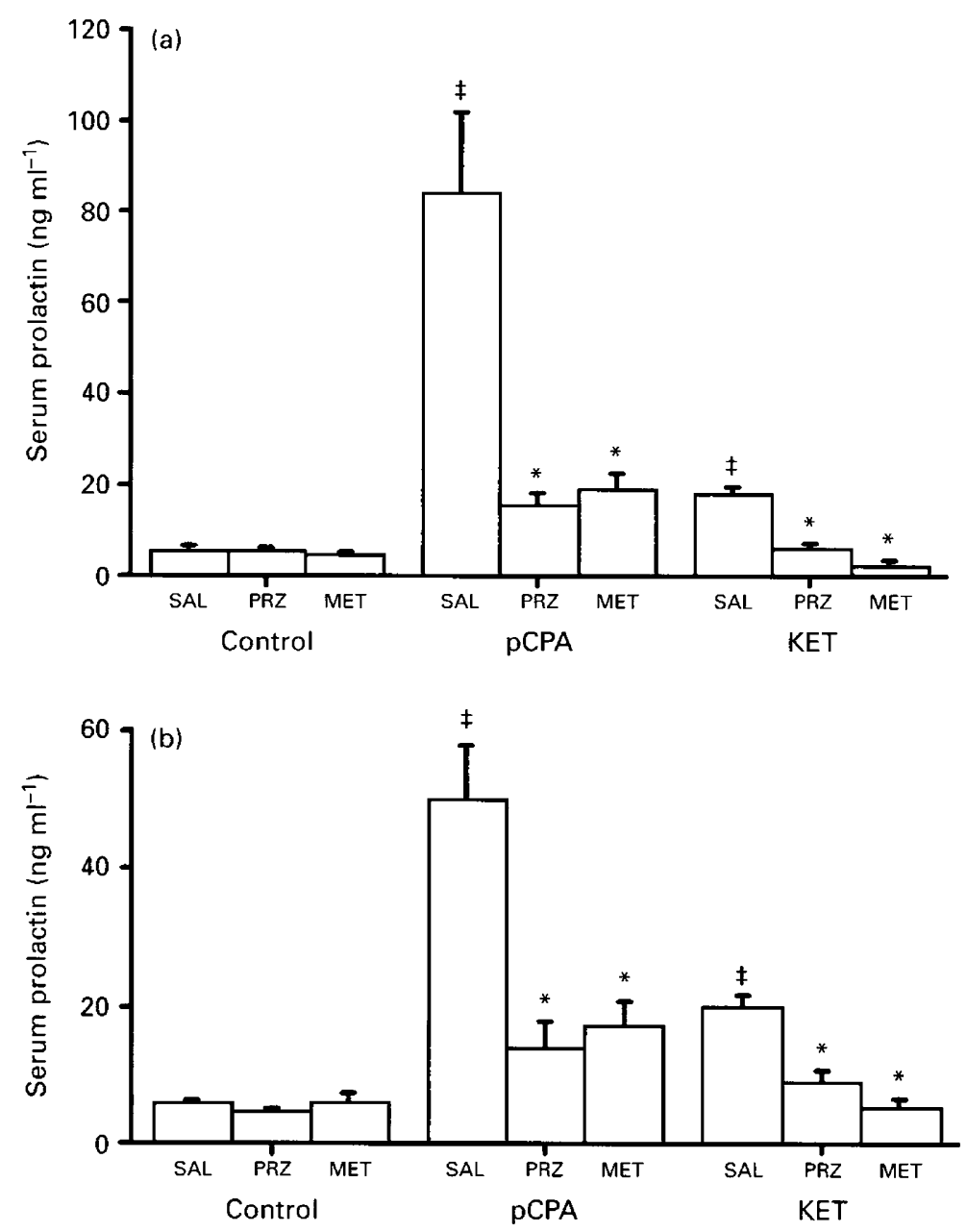

Fig. 3. Effect of adrenergic antagonists, prazosin and metoprolol, on $p$ chlorophenylalanine ( $\mathrm{pCPA}$ )- or ketanserin (KET)-induced prolactin secretion in rats (a) on day 19 of pregnancy $(18: 00 \mathrm{~h})$ or (b) on days 10-12 of lactation $(16: 30 \mathrm{~h})$ after $8 \mathrm{~h} 30 \mathrm{~min}$ of separation from the litter. Pregnant or lactating rats were injected with $200 \mathrm{mg}$ pCPA kg-1 s.c. at $12: 00 \mathrm{~h}$ on the day before the experiment or with $10 \mathrm{mg} \mathrm{KET} \mathrm{kg}{ }^{-1}$ p.o. at $12.00 \mathrm{~h}$ on the day of the experiment. pCPA-treated, KET-treated, or control untreated rats were injected at 14:00 h with $3 \mathrm{mg}$ metoprolol (MET) $\mathrm{kg}^{-1}$ i.p. , $10 \mathrm{mg}$ prazosin (PRZ) $\mathrm{kg}^{-1}$ i.p., or saline (SAL) on the day of the experiment. They were bled by decapitation. $\ddagger P<0.05$ compared with control saline group. ${ }^{*} P<0.05$ compared with the respective PCPA- or KET-treated group (Snedecor and Cochran, 1967). Values represent the means \pm SEM of groups of eight rats.

pharmacological agents used, indicate the involvement of $\mathrm{S} 1 \mathrm{a}, \mathrm{S} 2 \mathrm{a}$ and $\mathrm{S} 3$ receptors in the inhibition of prolactin release at the end of pregnancy. Thus, 8-OH-DPAT, DOI and $\mathrm{mCPBG}, \mathrm{S} 1 \mathrm{a}, \mathrm{S} 2 \mathrm{a} / 2 \mathrm{c}$ and S3 agonists, respectively, were able to prevent the action of pCPA. The lack of effect of RU 24969 rules out $\mathrm{S} 1 \mathrm{~b}$ receptors, while $\mathrm{mCPP}$ provoked a partial response which did not achieve significance. Since mCPP is an agonist at the S1b, S2c and, to a lesser extent, S2a receptors, the lack of participation of $\mathrm{S} 1 \mathrm{~b}$ and $2 \mathrm{c}$ receptors is also indicated and the partial action of $\mathrm{MCPP}$ may have been due to some interaction with the S2a receptors (Cowen et al., 1990). These results confirm and extend previous conclusions regarding the inhibition of prolactin release by $5 \mathrm{HT}$ in pregnant rats and in lactating rats isolated from the litter (Jahn and Deis, 1987, 1988, 1994), although a stimulation of prolactin release in late pregnant rats using the $S 3$ antagonist ICS 205930 was not noted previously (Jahn and Deis, 1988). In contrast, in lactating rats isolated from the litter, ICS 205 930 increased prolactin concentrations (Jahn and Deis, 1994). This difference may be due to different sensibilities of the serotoninergic systems between pregnant and lactating rats for the $\mathrm{S} 3$ agents used.

The stimulatory effect of pCPA or KET on prolactin release in late pregnant or non-suckled lactating rats was prevented 
partially by prazosin and metoprolol, $\alpha_{1}$ and $\beta_{1}$ adrenergic antagonists, respectively. These agents also prevented the prolactin release induced by the progesterone decrease at the end of pregnancy (Jahn and Deis, 1991). These results indicate that the 5HT pathway that tonically inhibits prolactin release during late pregnancy may act through inhibition of a stimulatory noradrenergic pathway and that this pathway is also active during lactation. There are a number of reports indicating interactions between serotoninergic and adrenergic pathways (Pickel et al., 1977; Agren et al., 1986; Baraban et al., 1981). A modulation by $5 \mathrm{HT}$ of endogenous hypothalamic and hippocampal noradrenaline release through activation of S2 and S3 receptors (Blier et al., 1990; Blandina et al., 1991; Done and Sharp, 1992), and a tonic inhibitory action of serotoninergic neurones upon noradrenergic neurones terminating on the medial zona incerta and the dorsomedial hypothalamus (Tian et al., 1993) have also been described. Some of these relationships have been implicated in the regulation of pituitary hormone secretion (Conway et al., 1990; Done and Sharp, 1992). The present results may extend these interactions to the regulation of prolactin release.

Administration of PCPA to late pregnant rats resulted in decreases in dopamine in the arcuate nucleus and the anterior hypothalamus, and decreases in noradrenaline in the anterior hypothalamus and the suprachiasmatic nucleus. The tuberoinfundibular dopaminergic neuronal cell bodies, located predominantly in the magnocellular portion of the arcuate nucleus and the periarcuate region, are the main source of the dopamine that inhibits prolactin secretion at the pituitary. Thus, the decrease in arcuate dopamine concentrations without changes in its metabolite, DOPAC, indicates that it may be a decrease in dopaminergic transmission that is directly responsible for the increase in prolactin secretion. The fall in noradrenaline seen in the suprachiasmatic or anterior hypothalamic nuclei is unexpected, since the results indicate that noradrenaline mediates the PCPA-induced increase in prolactin at this stage of pregnancy. However, in these areas, noradrenaline may not be associated with changes in prolactin secretion in late pregnancy.

In conclusion, the present results indicate that the inhibitory action of $5 \mathrm{HT}$ on prolactin release that is operative in late pregnant and lactating rats isolated from the litter seems to be mediated by coarse axon serotoninergic pathways, bearing S1a, S2a and S3 receptors, which inhibit the action of a stimulatory adrenergic pathway. In addition, this serotoninergic inhibitory pathway may regulate dopamine concentrations in the arcuate nucleus to control prolactin release.

This work was supported by a grant (PID 9036/01) from the Consejo Nacional de Investigaciones Científicas y Técnicas (CONICET), Argentina. Part of this study was performed during a sabbatical stay of G. A. Jahn at the Department of Obstetrics and Gynaecology of St. George's Hospital, London, in 1994, financed by the Cooperation Program between the Royal Society and CONICET. The authors are indebted to F. E. Guiñazu de Di Nasso for her excellent technical assistance. They thank the NIADDK for the gift of the prolactin radioimmunoassay kit. R. P. Deis and G. A. Jahn are career scientists from the CONICET.

\section{References}

Agren H, Koull M, Saavedra JM, Potter WZ and Linnoila M (1986) Circadian covariation of norepinephrine and 5HT in the locus coeruleus and dorsal raphe nucleus in the rat Brain Research 397 353-358

Appel NA, Contrera JF and de Souza EB (1989) Fenfluramine selectively and differentially decreases the density of serotonergic nerve terminals in rat brain: evidence from immunocytochemical studies fournal of Pharmacology and Experimental Therapy $249928-943$

Baraban JM and Aghajanian GK (1981) Noradrenergic innervation of serotoninergic neurons in the dorsal raphe: demonstration by electron microscopic autoradiography Brain Research 204 1-11

Blandina P, Goldfarb J, Walcott J and Green JP (1991) Serotoninergic modulation of the release of endogenous norepinephrine from rat hypothalamic slices Journal of Pharmacology and Experimental Therapy 256 341-347

Blier P, Galzin AM and Langer SZ (1990) Interaction between 5HT uptake inhibitors and alpha-2 adrenergic heteroreceptors in the rat hypothalamus Journal of Pharmacology and Experimental Therapy 254 236-244

Bradford MM (1976) A rapid and sensitive method for the quantitation of microgram quantities of protein utilizing the principle of protein dye binding Analytical Biochemistry 22 243-254

Burri R, Petersen SL and Barraclough CA (1987) Effects of p-chlorophenylalanine on hypothalamic indoleamine levels and the associated changes which occur in catecholamine dynamics and LH surges in estrogen-treated ovariectomized rats Brain Research 416 267-276

Clineschmidt BV, Zacchei AG, Totaro JA, Pflueger AB, McGuffin JC and Wishouski TI (1978) Fenfluramine and brain 5HT. In 5HT Neurotoxins pp 222-241 Eds JH Jacobi and LD Lytle. Annals of the New York Academy of Sciences, New York

Conway S, Richardson SL, Speciale S, Moherek R, Mauceri H and Krulich L (1990) Interaction between norepinephrine and 5HT in the neuroendocrine control of growth hormone release in the rat Endocrinology 126 1022-1030

Cowen PJ, Anderson IM and Gartside SE (1990) Endocrinological responses to 5HT. In The Neuropharmacology of Serotonin pp 250-259 Eds PM WhitakerAzmitia and SJ Peroutka. Annals of the New York Academy of Sciences Vol. 600, New York

Di Renzo G, Amoroso S, Taglialatela M, Canzoniero L, Basile V, Fatatis A and Annunziato L (1989) Pharmacological characterization of 5HT receptors involved in the control of prolactin secretion European Journal of Pharmacology 162 371-373

Done CTG and Sharp T (1992) Evidence that 5HT2 activation decreases noradrenaline release in rat hippocampus in vivo. British Journal of Pharmacology 107 240-245

Higgins GA, Joharchi N and Sellers EM (1993) Behavioral effects of the 5-hydroxy-tryptamine 3 receptor agonists 1 -phenylbiguanide and $\mathrm{m}$ chlorophenylbiguanide in rats journal of Pharmacology and Experimental Therapy 264 1440-1449

Jahn GA and Deis RP (1987) A possible dual regulation of prolactin release by the serotoninergic system in rats at pro-oestrus and during late pregnancy: role of ovarian hormones journal of Endocrinology 112 376-384

Jahn GA and Deis RP (1988) Effect of $5 \mathrm{HT}$ antagonists on prolactin and progesterone secretion in rats: evidence that the stimulatory and inhibitory actions of $5 \mathrm{HT}$ on prolactin release may be mediated through different receptors Joumal of Endocrinology 112 415-422

Jahn GA and Deis RP (1991) The involvement of the adrenergic system on the release of prolactin and lactogenesis at the end of pregnancy in the rat Journal of Endocrinology 129 343-350

Jahn GA and Deis RP (1994) Dual modulation of prolactin release by the serotoninergic system in lactating rats Journal of Serotonin Research 1 143-149

Jörgensen H, Knigge U and Warberg J (1993) Effect of selective 5HT receptor agonists on prolactin secretion in male rats Neuroendocrinology 57 401-407

Kellar KJ, Hulihan-Giblin BA, Mulroney SE, Lumpkin MD and Flores CM (1992) Stimulation of 5HT 1A receptors increases release of prolactin in the rat Neuropharmacology 31 643-647

Kleven MS and Seiden LS (1989) D-, L- and DL-fenfluramine cause longlasting depletions of 5HT in rat brain Brain Research 505 351-353

Kordon C, Blake CA, Terkel J and Sawyer CH (1973/74) Participation of 5HTcontaining neurons in the suckling-induced rise in plasma prolactin levels in lactating rats Neuroendocrinology 13 213-223

Kordon C, Drouva SV, Martinez de la Escalera G and Weiner RI (1994) Role of classic and peptide neuromediators in the neuroendocrine regulation of luteinizing hormone and prolactin. In The Physiology of Reproduction Vol. 2 pp 613-658 Eds E Knobil and JD Neill. Raven Press, New York 
Mamounas LA, Mullen CA, O'Hearn E and Molliver ME (1988) Dual serotoninergic projections to forebrain in the rat; morphologically distinct 5HT axon terminals exhibit differential vulnerability to neurotoxic amphetamine derivatives Journal of Comparative Neurology 314 558-586

Meek JL (1978) Studies of 5HT neurotoxins in discrete brain nuclei. In $5 H T$ Neurotoxins pp 190-197 Eds JH Jacobi and LD Lytle. Annals of the New York Academy of Sciences, New York

Molliver DC and Molliver ME (1990) Anatomic evidence for a neurotoxic effect of $( \pm)$-fenfluramine upon serotonergic projections in the rat Brain Research 511 165-168

Nissbrandt H, Waters $\mathbf{N}$ and Hjorth S (1992) The influence of serotoninergic drugs on dopaminergic neurotransmission in rat substantia nigra, striatum and limbic forebrain in vivo. Naunyn-Schmiedeberg's Archives of Pharmacology $34612-19$

Palkovits M (1973) Isolated removal of hypothalamic or other brain nuclei of the rat Brain Research $59449-450$

Pan JT and Gala RR (1988) The 5HT 5HT2 receptor system, but not the $\alpha 1$ adrenergic receptor system is involved in the estrogen-induced afternoon prolactin surge in the rat Life Sciences 42 1869-1874

Pan JT and Tai MH (1992) Effects of ketanserin on DOI-, mCPP- and TRHinduced prolactin secretion in estrogen-treated rats Life Sciences 51 839-845

Pan JT and Yang CH (1996) Central administration of 8-OH DPAT and mCPP stimulates prolactin secretion in ovariectomized, estrogen-treated rats: lack of an effect on tuberoinfundibular dopaminergic neuron activity Life Sciences $581189-1194$

Paxinos G and Watson C (1982) The Rat Brain Stereotaxic Atlas Academic Press, Sydney
Pickel VM, Joh TH and Reis D (1977) A serotonergic innervation of noradrenergic neurons in locus coeruleus. Demonstration by immunocytochemical localization of the transmitter specific enzymes tyrosine and tryptophan hydroxylase Brain Research 131 197-214

Quattrone A, Schettini G, Annunziato L and Di Renzo G (1981) Pharmacological evidence of central serotoninergic receptors involved in the control of prolactin secretion European Journal of Pharmacology 76 9-13

Sanders-Busch E and Steranka LR (1978) Immediate and long-term effects of $p$ chloroamphetamine on brain amines. In 5HT Neurotoxins pp 208-221 Eds JH Jacobi and LD Lytle. Annals of the New York Academy of Sciences, New York

Snedecor GW and Cochran WG (1967) Statistical Methods Iowa State University Press, Iowa

Soaje M and Deis RP (1994) A modulatory role of endogenous opioids on prolactin secretion at the end of pregnancy Journal of Endocrinology 14097-102

Soaje M and Deis RP (1997) Opiodergic regulation of prolactin secretion during pregnancy: role of ovarian hormones Journal of Endocrinology 155 99-106

Tian Y, Eaton MJ, Goudreau JL, Lookingland KJ and Moore KE (1993) Neurochemical evidence that 5-hydroxytryptamine neurons tonically inhibit noradrenergic neurons terminating in the hypothalamus Brain Research 607 215-221

Vermouth NT and Deis RP (1974) Prolactin and lactogenesis after ovariectomy in pregnant rats: effect of ovarian hormones Journal of Endocrinology 63 13-20

Wilson CA (1979) Hypothalamic neurotransmitters and gonadotrophin release. In Oxford Reviews of Reproductive Biology Vol. 1 pp 383-473. Ed. CA Finn. Oxford University Press, Oxford 